and agricultural activities enabled shipbuilding's worker-peasants to resist migration and proletarianization. By integrating industrial production into long-standing patterns of rural work, these worker-peasants retained their traditional community. Their workshop concerns reflected their identity as peasant owners intent on maintaining traditional modes of life and, as such, diverged sharply from the strike agenda of urban workers.

\title{
Eighth International Conference of Europeanists
}

\section{Michele Peterson}

University of Pittsburgh

The Eighth International Conference of Europeanists was held in Chicago on March 27-29. 1992. Seeking to hold a conference that included a wide range of topics and disciplinary approaches, the sponsor - the Council for European Studies (Columbia University) - chose not to impose a unifying theme. Scholars from Europe and the United States participated on more than forty panels dealing with historical and contemporary aspects of European society, culture, economics, and politics. Almost all of the panels covered more than one country. and several focused on the ongoing transformation of formerly communist countries. Perhaps due to Germany's influential position in an emerging integrated Europe, papers dealing with the former East and West Germany were presented in well over half of the sessions.

The panel "Gender and Politics in Early Twentieth Century Europe" considered various social constructions of class and gender, and the degree of continuity and rupture in modern Europe. Mary Nolan (New York University) argued that the ideology and practice of Germany's social rationalization movement during Weimar (in particular, the German Institute for Technical Work Schooling or DINTA) helped create the later Nazi system of industrial relations and worker education in the factory. DINTA and other practitioners of social rationalization called for a world where masculine and feminine spheres were separate where women devoted themselves to husbands and children, and men "joyfully fought the battle of production." Its efforts in the 1920 s contributed to a vision of the ideal male worker and reformed working-class family which proved useful to employers in the Third Reich as well as after 1945.

While Nolan's paper revealed important elements of continuity between Weimar and post-1932 Germany, Atina Grossmann (Columbia University) emphasized 1933 as a point of rupture for German sex reform and social medicine. Weimar social reformers, according to Grossmann, were not worn down by years of eugenic discourse and readily persuaded to support Nazi public health policy for the sake of Volksgesundheit (public health). On the contrary, they had to be fired, arrested, and forced to emigrate after 1932. Both papers demonstrate the need for a finely grained understanding of the balance between break and continuity in twentieth-century Germany. In her paper " 'Sherry and Silks:' The Promotion of Women's Pleasure in London's West End," Erika Rappaport (Rutgers University) analyzed 
the connection between a redefinition of middle-class women and the rise of mass consumption in the late nineteenth-century England. She concluded that English department-store owners built an image of their stores as an "all-female space" in the effort to win support for their controversial institutions; new acceptable ideals of femininity developed as part of the legitimation of a new form of market practice. In the fourth paper, Karen Hagemann (Technical University of Berlin) examined the lives of working-class women in Weimar Germany. While many elements of "men's politics" were based on concerns stemming from "women's daily lives," she maintained that Weimar's labor movement offered only a restricted vision of women's role and status.

The session "Reconstituting Public Authority: Paternalism, Social Reform and Bourgeois Politics" looked at a number of social reforms, political responses, and attempts to restructure labor relations within the firm in modern Europe. Dennis Sweeney (University of Michigan) argued that social reform efforts in the Saar at the turn of the century included much more than attempts to improve working-class material conditions. The efforts encompassed a cultural project that had at its center the conversion of workers into "respectable" citizens, embracing the values and norms of their superiors. In Hamburg, according to Michele Peterson (University of Pittsburgh), office workers responded to increasing manager control over the work process by cultivating their own "respectable" sense of identity as Privatbeamten - special employees in the private sector entitled to certain rights and privileges. Lars Tragardh (University of California, Berkeley) traced the concept of "the people" in Sweden and Germany in an effort to explain why Swedish Social Democrats succeeded in building a worker-peasant alliance in 1933, and why the German SPD failed. At the core of his explanation was the claim that while a strong popular democratic culture had existed in Sweden before 1933, such a political tradition had been relatively weak in the German countryside. Finally, Steve Soper (University of Michigan) examined how the themes of education and capital were joined in mid-nineteenth-century Italy to build a form of elitesponsored rule.

A third panel, "Unions and Industrial Relations in a Changing Europe," addressed the impact of European integration and German unification on organized labor in contemporary Europe. Lowell Turner (Cornell University) concluded that German unions have performed reasonably well in the face of major political and market transformations. Their success may be explained by the leverage afforded by particular national institutions, especially the works councils and large national unions engaged in regional-level collective bargaining. In response, the panel commentator. Wolfgang Streeck (University of Wisconsin, Madison), argued that European integration is, in fact, undermining the national institutions on which German union strength is based. Of particular interest to labor historians was Kathleen Thelen's (Princeton University) paper which compared the historical roots of shop-floor regimes in Sweden, Germany, Britain, and the United States. Defining shop-floor regimes as the arrangements that govern relations between labor and capital at the plant level, she distinguished between two basic patterns: regimes premised on "job control" (Britain and the United States) and those premised on "codetermination" (Germany and Sweden). Although both are concerned about the same issues, the point of intervention and influence in the latter case is the plant and in the former case is individual jobs. 
Finally, "Bürgertum, Borgare, Bourgeoisie: the Concept of the Middle Class in Europe and America" considered several distinct representations of the middle class. Madeleine Hurd (Harvard University) compared the German and Swedish middle classes, calling for a much more complex understanding of the lack of liberal success in nineteenth-century Germany. Fred McKitrick (Columbia University) concluded that the integration of German artisans into a modern industrial economy and into the broad middle class after 1945 was not brought about by a free marketplace. Rather, it was accomplished under the direction of corporate forms of organization which are generally assumed to be economically inflexible and politically illiberal. The effort succeeded because a strong sense of artisanal identity and tradition had been preserved within a corporate context that was high pragmatic.

Although the conference was not organized around a central theme, several conclusions emerged which are relevant to the work of social and labor historians. Many agreed on the need for more East-West comparisons in European studies, and the need for greater emphasis on Europe's relations with other regions of the world. Continuing attention should be paid to the contributions of poststructuralist social and cultural theory in understanding the lives of working-class men and women and the history of labor movements.

\section{Organization of American Historians}

\section{David Morrison}

University of Cincinnati

The 1992 Organization of American Historians (OAH) annual meeting, held in Chicago. featured a wide range of papers and panels devoted to labor history. The conference opened with a retrospective look at "Race and Class in Early America: The Works of Gary B. Nash." Like many others, this panel paid tribute to past idioms while also exploring new approaches. Richard Dunn (University of Pennsylvania), who taught Nash at Princeton, began the session by noting Nash's work both as an archival scholar and in high-school curriculum development. Allan Kulikoff (Northern Illinois University) praised Nash for developing a model of class formation in colonial America but saw the need to bring rural peoples and household relations into the story. Similarly, Jean Soderlund (University of Maryland, Baltimore County) lauded Nash's early integration of race and class while lamenting his neglect of gender.

In "Labor at the Ballot Box," the papers presented intriguing approaches to labor's source of political power. "Labor and the Democracy of Bryan and Wilson: The Origins and Impact of a Progressive Era Alliance" by Julia Greene (University of Missouri-Kansas City) examined the relationship between the American Federation of Labor (AFL) and the Democratic party. Greene found that the AFL's inability to deliver its members' votes, coupled with its increasing antistatism, led the Democrats to abandon the union and seek a direct alliance with the working class. Eric Leif Davin (University of Pittsburgh) presented "SWOC Takes 